\title{
Birds in their Relation to
}

\author{
Agriculture
}

\section{REMOTE STORAGE}

\section{The Wealth of Montana}

\section{as Shown by Statistics}

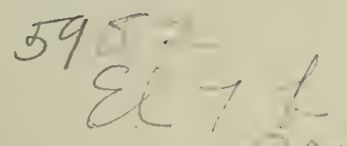

B Y MORTON J. ELROD

University of Montana

Reprint from Second Annual Report, Montana State Board of Farmers' Institutes, pages 173.190 and $197 \cdot 208$, with $\delta$ plates.

University of Montana, Missouia, Montana, U. S. A.

1904 



\title{
THE RELATION OF BIRDS TO AGRICULTURE.
}

\author{
By Morton J. Elrod, University of Montana.
}

Bird protection may be studied from two standpoints, the sentimental and the economical. We have little to do with the former in this discussion, although there is much to be said. To discuss the use of birds as human ornaments is a subject by itself. The small boy, and sometimes the larger one, comes in for his share of censure. The birds have a right to live, so long as they are not a menace to human beings, and their rights are respected by fair and thoughtful people.

But we are to discuss birds from the economical standpoint, in dollars and cents. This may for convenience be divided into four heads: I. Birds as food for man; 2. Birds as protection from insect ravages; 3 . Birds as destroyers of weed seeds; 4. Birds as destroyers of noxious birds and mammals. Later we shall take up some of the few birds that do injury to man by destroying his crops, his fruit, his orchards, or his poultry. All of these are overestimated when the facts are considered.

I believe it is Prof. Forbes who says: "It is hard to balance the good things one reads about an animal by the the bad things he sees." The few observations made by the average person weigh heavier than all his reading. He sees a bird destroy a chicken, or eat some cherries, or pick up some grain, and immediately comes to the conclusion that the bird is destructive to his interests and should be killed. The scientific method of gathering all the facts obtainable and making a careful examination before coming to a conclusion is the theme of my brief discourse.

Each species of plant and animal has a tendency to spread. It is provided with some means for distribution. If left unchecked, and without enemies, it will, under favorable circumstances, cover the entire earth. Many species of both plants and animals have a very wide distribution, and the territory covered by them is constantly becoming wider. This tendency to migrate has given to different localities their present faunas and floras. To make a study of geographical distribution of plants

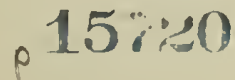


is an absorbing theme, and one that has been of great service to the naturalist as well as the farmer and fruit grower.

To elaborate the idea advanced a few illustrations may be made. Let us first take the English Sparrow. This is the common sparrow of England, which at home is not a nuisance nor a disturbing element. It was introduced into America in I850 at Brooklyn. The first introduction was a failure. Later, in I853, it was again introduced, a large lot being liberated in Greenwood Cemetery, New York. Successive importations were made during the next twenty years. It has no enemies, and found an abundance of food in the city. From that introduction the species has spread until at the present time it has covered almost the entire United States. It has been persecuted, bounties have been laid by legislatures, war has waged against it on every. side, and still it thrives. At the present time it is even in the mountain state of Montana. From the east it has come by the railways, those great high-ways of commerce, as far as Great Falls. At Culbertson it is abundant, less so at each town westward, until at Great Falls a small colony became a fixture less than two years ago. By the Northern Pacific it has come from the east along most of the road in Montana. From the south it has come to Butte, Anaconda and Helena. It has not reached Missoula, but will no doubt be seen there before long. I well remember how a few years ago, I think it was in 1899 , the late C. A. Wiley, of Miles City, bemoaned its arrival that year in Miles City.

Another illustration is the Gypsy moth. Some years ago an eastern entomologist received some eggs of this moth from England, for the purpose of experimentation. The eggs came in a paper, which was opened in the study. A gust of wind scattered the eggs, most of which were gathered up. Twenty years afterward there was an outbreak of the moth. The state of Massachusetts has spent nearly two millions of dollars in attempts to hold the pest in check, and it will take millions yet before they are through with it.

Then we may note the San Jose scale. This was first discovered near San Jose, California, in I880. Hence its name. Until recently its nativity was not known. It is now believed to have come from China. This scale attacks the bark and stem of young trees, covers the twigs, leaves, and even the fruit, in such great numbers that the tree may be destroyed. It is one 
of the worst pests for the orchard. It was next seen along the Atlantic coast, and has spread over the entire United States. At present it is not in the orchards of the State, although it has been taken on fruit shipped into the state.

We might mention the Russian thistle in America, the introduction of the mongoose into Jamaica for the purpose of destroying the mice in the cane fields, and dozens of other illustrations. But it would require too much time, although it would make interesting reading.

Of all the progeny of plants or animals but few survive. An adult lobster may deposit a hundred thousand eggs. Yet no more than a score are likely to reach maturity. The eggs of a tape worm stand one chance in a million of reaching a suitable place for development. If a single bacterium should be permitted to multiply and the progeny supplied with food and moisture suitable for development more than seventeen millions would be in existence by the end of twenty-four hours. If a single paramecium, one of the low one celled animals, should be given food and warmth for the uninterrupted development of the offspring resulting from fission the number resulting in thirty days would be $268,000,000$. If the young of a single pair of robins should be permitted to live and multiply the number of robins in ten years from this pair would be very great.

But nature seems malevolent. Of all the great number that is possible but few develop. There is a constant thinning out of numbers by enemies, climatic conditions, lack of food, and so on. The fittest survive. It is give and take. Some cannot endure the struggle, and die off. Some have little struggle, and become very abundant. But Nature has a tendency to strike a balance at last. The time usually comes when numbers are of no avail, and by their very numbers the race is imperiled. The mongoose was finally held in check by the tick. The little lady bird beetle bids fair to hold in check the San Jose scale. Bacteria are usually held in check by the living cells of the body. Few species of plants or animals overrun the earth, although the tendency is to do so. But the time necessary to find a remedy for an evil such as has been mentioned is sometimes very great.

Man is quite likely, through ignorance, to overturn the balance wheel of nature, so to speak, and send the whole machinery to smash. This is the case in the introduction of species of animals and plants to a new locality, where the conditions are new, and 
where enemies are lacking. It therefore behooves us to look carefully into the question of what the result will be if the birds are killed off in large numbers, for the statistics show that they are going very fast. The study of game birds will have little to do with this question as it is presented to us as stated, from the fact that game birds are very few, and with the advent of man must disappear. It is to be regretted, but it must be so. The only thing we can do is to use our best efforts to keep them as long as we can, and possibly preserve from year to year a few remnants of a fast disappearing group of birds. The grouse family is the great family of game birds. In some places the turtle dove is shot for food, and in others meadow larks, bobolinks or rice birds, are killed. Our present laws are inadequate for the protection of these birds. A man may kill twenty of each species each day during the season. For ducks there is no limit as to the number killed. Since the last game law has been declared unconstitutional there is no protection for ducks from the first of September to the first of May.

t The methods employed to determine whether birds are useful or harmful as insect destroyers or as seed gatherers, will be of interest to some. The fate of a bird is a very important item. If it is charged with crimes which it does not commit we cannot excuse ourselves for the crime of killing it off. To kill off a bird without trying it fairly is not in accord with the spirit of fair play that is so prominent in all the actions of the American people. How shall we determine whether or not a bird is our friend or our enemy?

The United States Department of Agriculture is doing much work in this direction, and the results so far are of far reaching importance. The study necessarily involves the killing of a large number of birds. But this killing is justified, for by their loss thousands will probably be saved through the study of the birds slain. The birds of a given species are taken at all seasons when they are to be had, in all parts of the country. It is not fair to take them at the time they are supposed to be doing damage and at no other. The good must be balanced against the evil. Perhaps hundreds of birds will thus be killed in different parts of the country. The stomach of each is removed and preserved. Later the contents are examined by specialists. It is not a very pleasant occupation to examine the contents of hundreds of birds, working over pieces of ants, wings of beetles, parts of spiders, 


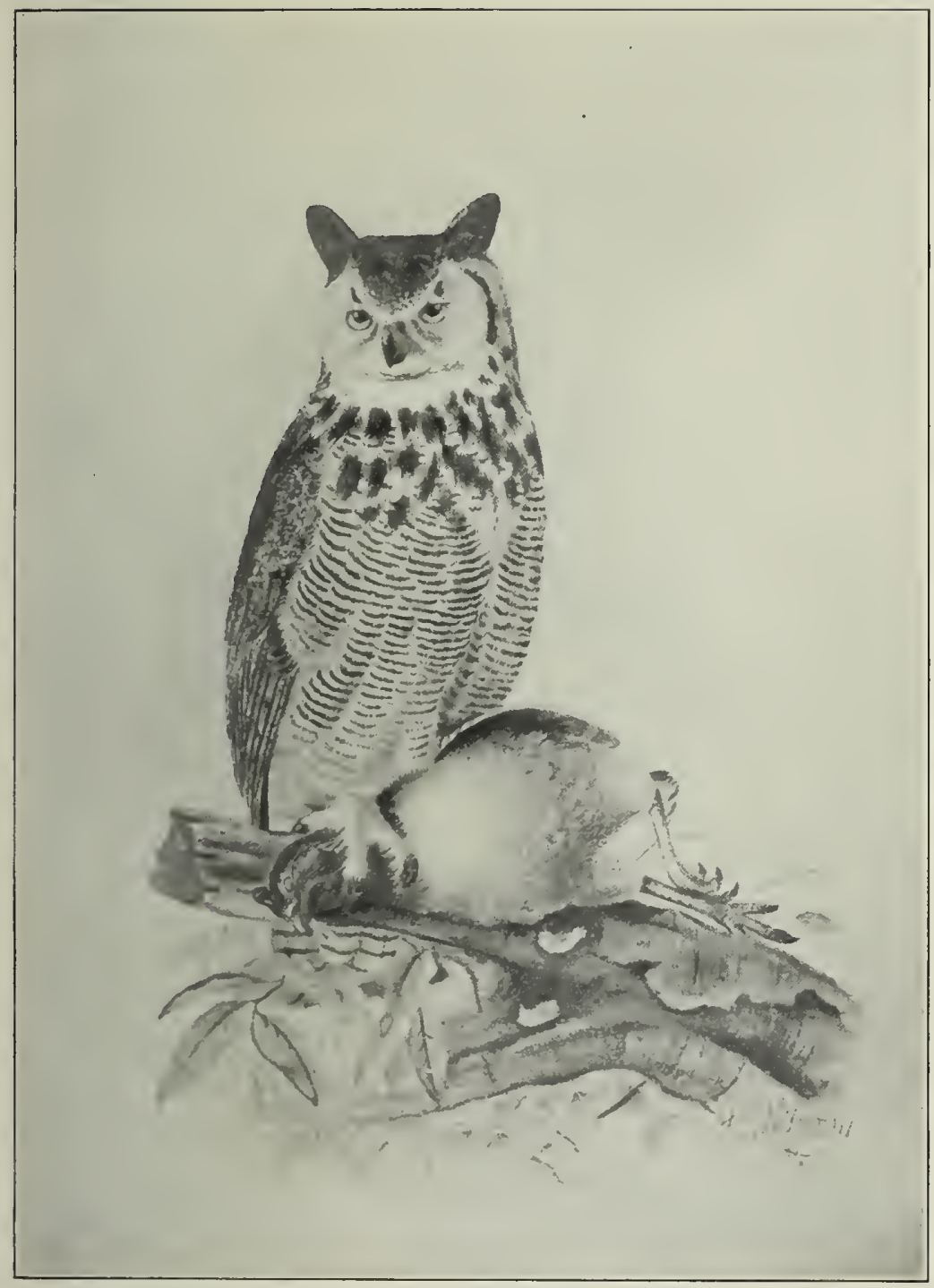

Great-horned Owl, Bubo virginianus Gmel. From Biological Survey. \&.. 


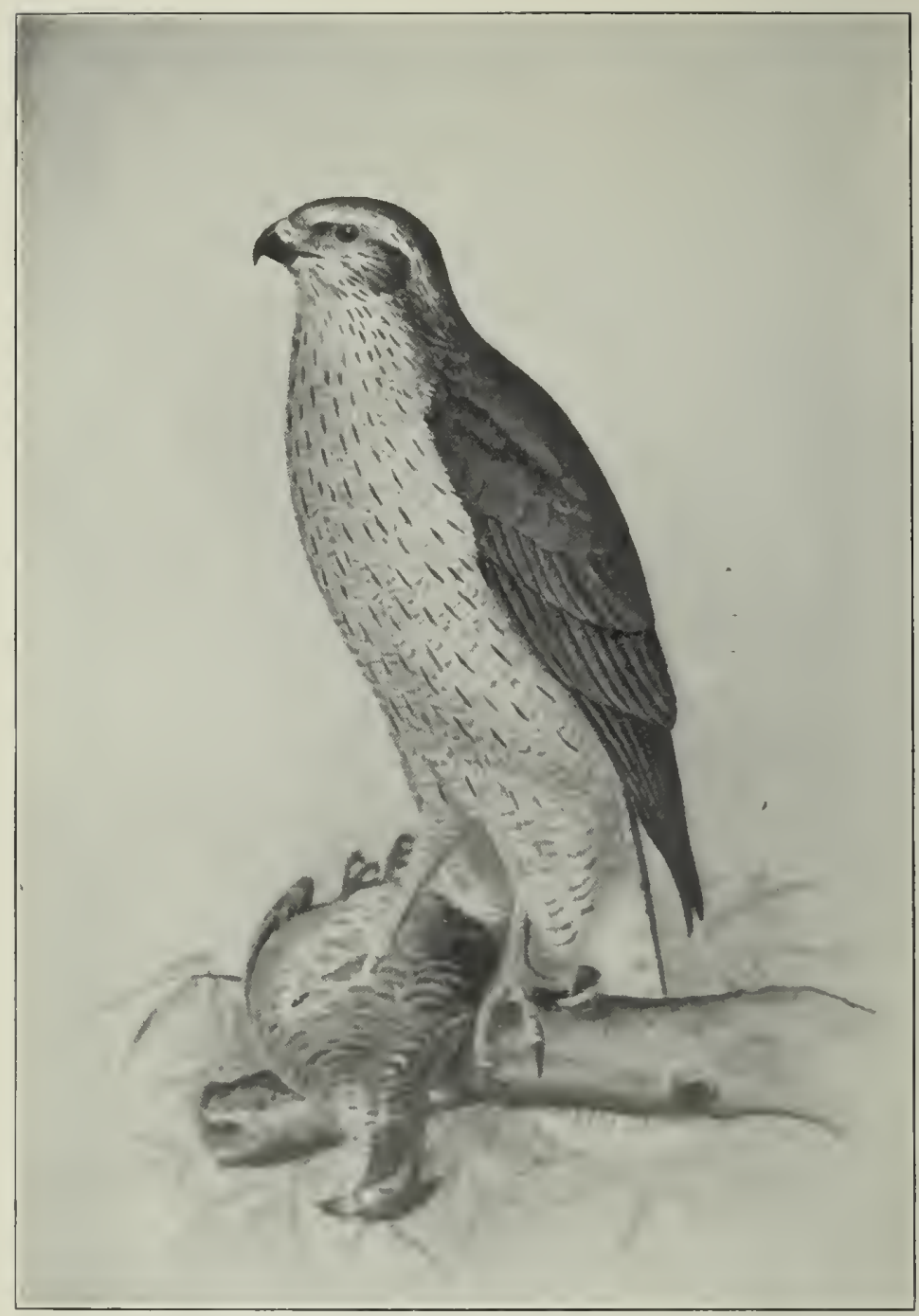

American Goshawk, Accipiter atricapillus Wilson. From Biological Survey. 
half digested grain, portions of fruit, and the like. But this must be done. It requires no small amount of information on the part of the examiner to do this intelligently, and the work is necessarily slow and expensive. The different things found in the stomachs are then arranged and tabulated, including everything that can be determined, whether beneficial or injurious to man. This is then figured in per cent of the different ingredients. By this means the food of the bird for the season is determined. Also, if there is a difference in different localities it is determined. The results are published, and are available on the part of any one interested so long as they may last. All that is necessary is for the person interested to address a letter to the Secretary of Agriculture, Division of Biological Survey, Washington, D. C., and ask for literature relative to beneficial and injurious birds. In this manner many birds have already been studied. To give a summary of the work would be unnecessarily tedious, and would be useless since it is available in printed form. Appended to this paper will be found a list of papers, many of which are yet obtainable, which relate to the subject.

Much of the information which I am able to present has been gathered from the sources previously mentioned. Indeed, if I were to claim originality in what I am able to give, I would be presumptuous. Let us find from the statistics of what importance the study is financially.

It is estimated that $\$ 200,000,000.00$ are lost annually to the farmers and fruit growers of the United States through the ravages of insects. This is one-tenth of our total agricultural crop. To lose one dollar in ten is a heavy toll to pay the insects. This toll is especially heary from the fact that it usually falls on some section or sections of the country, when the crop for over a large tract may be completely destroyed. The number of birds in species in the entire North America, according to Ridgway, is about 800 . There are over one hundred thousand species of insects, and most of them are injurious. The injuries come from the young or larval insect, either through destruction of the foliage as food, or by sucking the life out of the plant with the beak. or by penetrating to the interior of the leaf or stem, there eating the vital part of the plant as food or making a cavity for the deposition of eggs.

An examination of the statistics show that birds are great destroyers of weed seeds. Most weeds produce seeds in great 
abundance. If this were not so the species would soon become extinct. I have watched the grosbeaks every winter eating the seeds from the box-elder trees in my yard. I have watched the cedar waxwings strain their little necks to reach the wild rose apples. What a beautiful sight it is to see the male, with his dash of brilliant scarlet on the wing, craning his neck for a rose apple scarcely less beautiful, the bush swaying back and forth with the weight of the bird, which must use both legs and wings to keep position. I have watched the horned larks as they sought the apparentlv barren plain in search of food, sometimes going in flocks of hundreds. I have killed the Rocky mountain jay when his cheeks were crammed with nuts from the yellow pine, which he was evidently storing for food. Who has not seen the little sparrows on the almost barren ground searching for food. During the migration period the university campus at Missoula is alive with sparrows, quietly searching the weeds for a meal. Prof. Beall has estimated that the tree sparrow alone in' the United States destroys annually $1,720,000$ pounds of seeds of noxious weeds. Every person should recognize the sparrows. They are small, usually of a gray or slate color, with short and thick bills. The bills are specially adapted to cracking seeds: These birds are very useful, and should by all means be preserved. They are friends to the farmer and fruit-grower, and should receive his protection.

Birds are the natural enemies of insects. In the woods one may find the little warblers, a large and interesting family of birds. These are built on a different plant from the Fringillidae, or seed eaters. The Mniotilidae, or warblers, are small and trim little fellows, often with bright and even gaudy colors. Their bills are small and slender, specially adapted for piercing the body of an insect larva. These birds may easily be recognized. and are as useful as Fringillidae or finches, but in another way. They are largely migrants, spending the summer with us, when the young are reared. The winter months are spent farther south, whither they go about the first of October. Some go much earlier. During their stay with us they are engaged in the daily occupation of gathering food and rearing their young. The food consists largely of insects, which they seem to search constantly. These birds no doubt destroy insects which, without the birds, would perhaps destroy much vegetation. Since it is estimated that on the average each bird in the country de- 
stroys as many as 2,400 insects one cannot even speculate as to the number of insects destroyed.

Statistics relative to the increase or decrease of birds in the United States are scarce and hard to secure. A few years ago G. O. Shields, editor of Recreation, secured opinions from hundreds of persons all over the United States relative to the number of birds at that time compared with ten years previous. The result was astounding. The opinion prevailed that the number of birds in a given section of the country had greatly decreased during the decade. In many cases the decrease was as much as fifty per cent. While the statistics are only opinions based on observations by careful observers, it is safe to assume that birds in the greater portion of the country are on the decrease, and that very rapidly. This is greatly to be deplored, for with the decrease has come a great increase in insects, which have wrought great destruction. What are the causes for the killing of useful birds?

First may be mentioned the elements. Severe winters often destroy birds in great numbers, especially when they migrate early and are then overtaken by severe storms, when food cannot be obtained. But the elements are insufficient to account for the great mortality. Their natural enemies kill a large number. These enemies are snakes, birds of prey, weasels and other mammals. Then comes the domestic cat. In thickly populated districts the cat is abundant. It is a great destroyer of birds, and if statistics could be secured it would be responsible for a very large number of birds. There can be no question but that the cat is a menace in many localities, and should be killed in large numbers. In cities the cat, the English sparrow, and the boy, have driven the birds practically from the region. Then comes the great enemy of the birds, often unintentional and without giving thought, man. The desire to kill is inborn in the human breast. It is an instinct borne of a distant past, when might was right. A boy or a man with a gun must shoot something. A stone on a fence post is not half so tempting for a shot as a woodpecker or a meadow lark. The unsuccesșful attempt to bring in a rabbit, a quail or a pheasant is likely to result in the destruction of a few birds, just to bring down something. The small boy with fire arms does untold destruction to bird life. The pump gun has almost destroyed the grouse and duck, and if the automatic gun is not squelched before it is put 
on the market the last of the feathered tribe is not very far distant in time. Then woe to the farmer and horticulturist. 'Laws are not sufficient to stop the destruction. Public sentiment must be aroused to the great value of our feathered friends, and the wanton destruction that so often prevails. In the eastern and middle states severe laws are now in force. In some cases these stringent laws came late-too late to be of best help in saving the birds. But even with stringent laws the mortality continues and the decrease becomes greater with each decade.

From the best information obtainable it appears that birds are on the increase in this state. This is to be expected. The state is large and the inhabitants comparatively few. Large tracts of land have been put under water through irrigation, thus making food more abundant and making it possible for a greater number of birds to live than formerly, and also providing food for different species than is the case when the land is in its natural state. All the old timers who have been close observers seem to think that birds are more plentiful than formerly. There is still much land in the state to be brought under cultivation. Large irrigation schemes are under construction both by the government and by private individuals. Hundreds of thousands of acres now growing but a small amount of grass will in the next one or two decades be producing crops, and furnishing homes and food for thousands of people. With this influx of people and accompanying this large acreage of farming must come the countless hordes of insects that will find food and home. They will surely come, and we may as well make way for them and prepare for them. At the same time we may expect a large addition to our avifauna. With the disturbance of the balance of nature on so large a scale no one can predict which will be the greater in relative numbers. It is reasonable to suppose that the insects will be the first to arrive, and that the birds will be slower. We have the birds. They seem to be on the increase with us. We can do much to aid in their propagation by making the conditions favorable. How can this be done?

First, by executing the laws of the state, and enforcing them on those who kill birds contrary to law. The game warden will furnish copies of the laws to all who may make inquiry, so there is no need of pleading ignorance. Second, by developing a healthy moral sentiment among the people, and esperially amung the youth in the public schools. This may be done by example, 


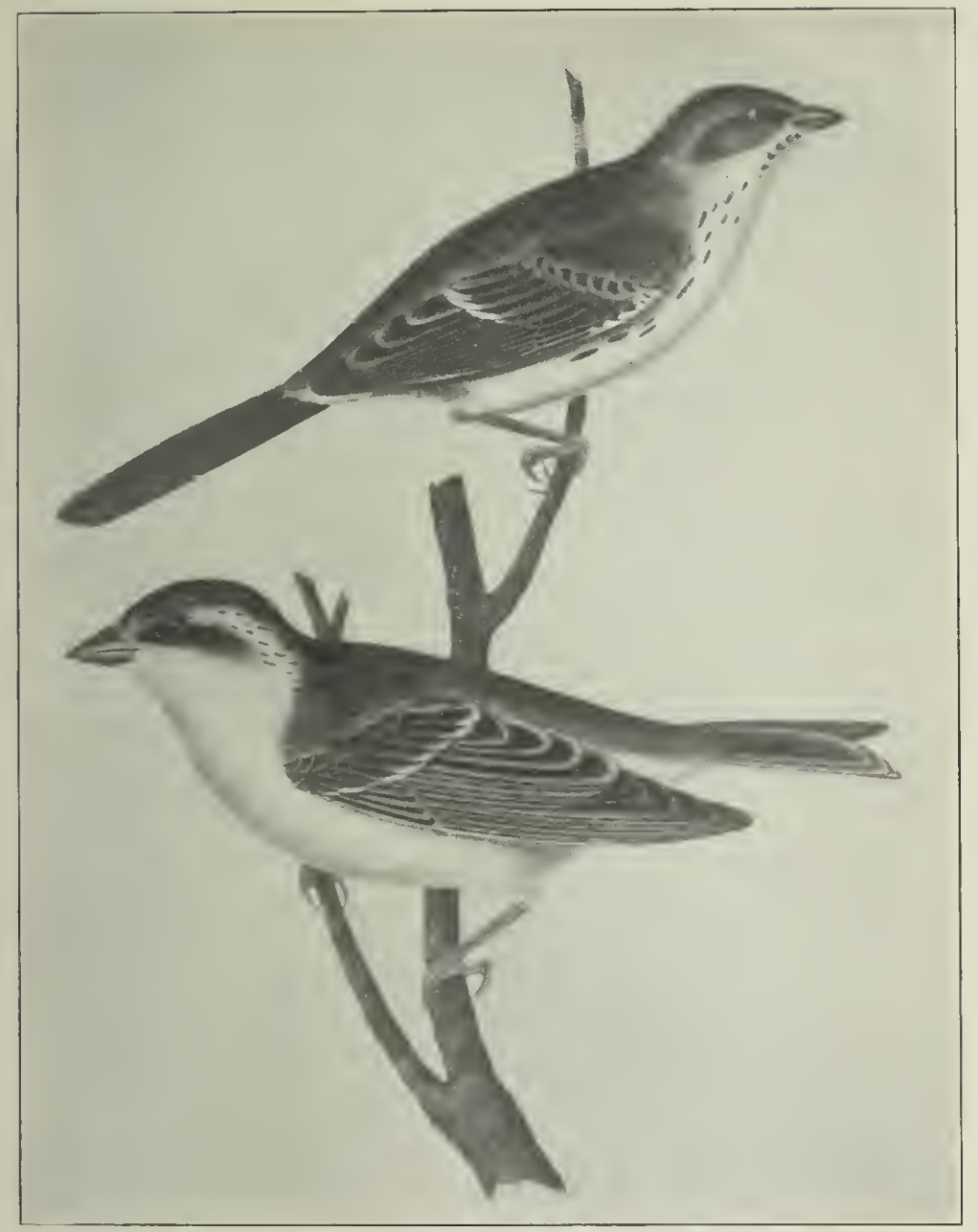

Types of finches, or seed eating birds. The upper the desert song sparrow, Mellospiza fasciata fallax (Baird). 't he lower is Cassin's purple finch, Carpodacus cassini Bairl. From U. P. R. R. Survey. 


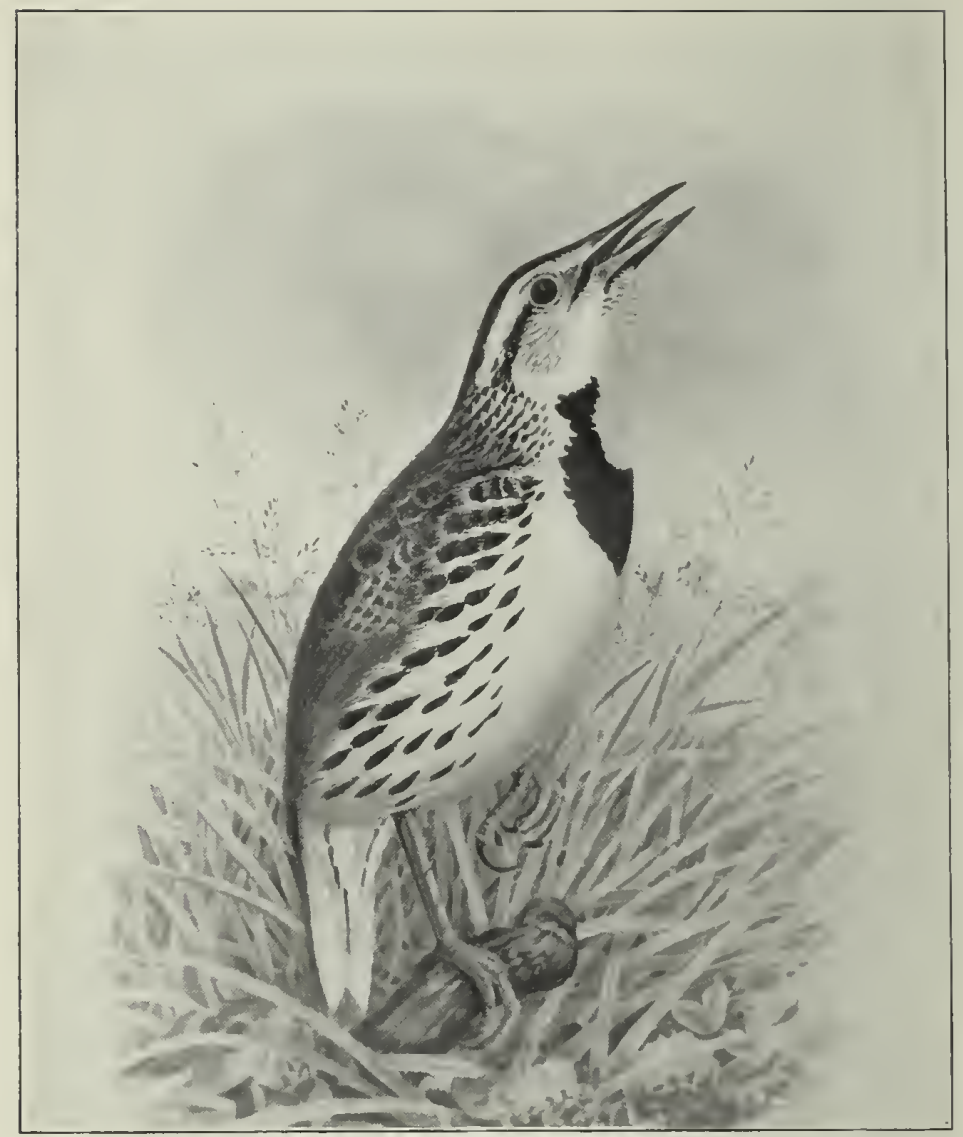

Meadow Lark, Sturnella magna. From Ornithology of Illinois. The western lark is Sturnella magna, var. neglecta. 
by good literature, and by giving information relative to the habits of birds. No thinking person can study birds without having increased love and sympathy for them. Third, by providing suitable places for them to use as nesting sites in which to build and rear their young. This may seem of little avail where the country is so vast and the population so scanty, but if each one does his best the result must be to help in the increase. In a recent trip of several hundred miles but one bird box was observed, and that was placed by a small boy. We need more such boys, and more such nesting places. The fiycatchers must seek the commutators on electric light poles, or the eaves of houses, when they should have nice boxes, free from interruption and safe from the cat.

The work of the farmer and the fruit grower in the state is but in its infancy. Nearly a quarter of millinn fruit trees were planted in the state during the past year. When all the orchards in the state shall be bearing what a harvest it will be. In all portions of the state increased acreage is made in wheat, meadow, alfalfa, barley, and other grains and grasses. We have the experience of the past and of the eastern states for our heritage. We have the birds, and we know their value. If we do not take advantage of the conditions the fault must lie with us.

What is the number of birds in the state in species? When we talk of the different species we mean what is generally referred to by the word kind. All the birds that are called by the name great horned owl are of one species. All the countless English Sparrows are included in but a single species, Passer domesticus. Observations have been made during the past five years on the birds in the region about Flathead lake. This is a good field for the ornithologist in many respects, and the work accomplished by the University of Montana Biological Station is the first systematic study of the bird fauna of the state. The results obtained through the dilligent efforts of Prin. P. M. Silloway and others show but I37 species, including all species of summer residents, summer and winter residents, spring and fall migrants. This is not a large number, and many of them have but a few scattered specimens. In the bulletin "Birds of Fergus County," by P. M. Silloway, recently issued by the school board of the Fergus County Free High School, I75, species are listed. Fergus county is about as large as the state of Massachusetts, and is in the great Misouri river highway, up 
which so many birds and animals have come from the Mississippi river and the Great Plains. Miles City shows a list about as large as that from Fergus County. The entire avifauna of the state will no doubt be much less than most people expect, and certainly will not exceed a few hundred. Of this number what proportion are injurious?

We may now hastily examine the records relative to few birds, some of which are on the doubtful list, others clearly proven to be injurious, and deserving of no protection.

Grave charges have been made against the robin. In some localities he is persecuted during the cherry season. No charge seems to be made against him at other times. Let us examine the charges, and see if they are well founded. The robin is one of the earliest harbingers of spring. He is known to all, and his cheerful song in the early morning or late evening as he takes his position on the cupola of a building or on the topmost bough of a tree has been the theme of poets for years. After their arrival in spring they often roost in large numbers in some locality. They have been known to go a hundred miles for breakfast, and arrive at the feeding ground shortly after sun up. In the evening they return to the roost, a hundred miles on the return. Thousands will congregate in these roosts. Later they pair off and the pairs seek some suitable place in which to build a nest and rear the young. They are principally ground feeders, as may be recognized by their long and stout bills, although they have bills much smaller than the orioles, which are typically ground feeders. The food of hte robin consists of larval insects, worms, beetles, occasional mollusks, spiders, insect eggs, and fruit, both wild and tame. Prof. Forbes says: "I do not believe that the horticulturist can sell his small fruits anywhere in the ordinary market of the world at so high a price as to the robin, provided that he uses proper diligence that the little huckster does not overreach him in the bargain. In other words, while the bird is far too valuable to exterminate, at least until we are sure we can replace fim by some cheaper assistant, yet he is not so precious that we need hesitate to protect ou: fruits from outrageous injury. Indeed it seems likely that the ordinary destruction of robins by gardeners does not more than compensate for the destruction of birds of prey in the interests of the poultry yard--removing that 
excess of robins which, in the more natural order, would fall victims to the hawks and owls."

Mr. W. F. King, in Vol. I of the Wisconsin Geological Survey says of the robin: "In its method of obtaining food and in the situation from which its food is gleaned, the robin performs a very important work, and one for which few other birds are so well adapted. So important is this work that the quantity of small fruit which it consumes is but a stingy compensation for the service which it renders, and I know of no bird whose greater abundance is likely to prove of more service to the country." He examined thirty-seven stomachs.

Dr. E. V. Wilcox examined 187 stomachs in Illinois. He says in his summary, "the fruit-grower should at least be allowed to kill the robin during the season. when he is most harmful, and not, as at present, be in danger of arrest and fines for shooting the robins in his own garden.'

Educational leaflet No. 4, referred to in the bibilography, says concerning the robin; "That the robin is a very beneficial bird there is no doubt, although it is claimed by some persons, especially small fruit growers, that it eats cultivated fruit to an injurious extent. This charge, the evidence shows, is confined to special localities and to a very limited period and is not all general. The horticulturist can protect his small fruit crops by growing a few wild fruits for the robins and the cultivated kinds will not be disturbed; but thousands of injurious insects will be eaten that would otherwise be a pest. A careful study of the food tables abstracted from data furnished by the Bioligcal Survey, United States Department of Agriculture, ought surely to convince everyone that the robin is a very valuable aid to the agriculturist and therefore ought to be carefully protected."

Statistics compiled show that for the entire year the food of the robin was as follows: insects, sixty-five per cent, cultivated fruits, twenty-five per cent, wild fruits, ten per cent. Of the insects about forty-five per cent are injurious, thirty-five beneficial, the remainder neutral. There are no statistics on the bird from Montana. Until we make a study of it we may well hold judgment in abeyance, since our wild fruits are so abundant and so luscious for birds.

The meadow lark is with us the first harbinger of spring. In most states the bluebird and the robin are first looked for 11 the days when winter is fast disappearing, but in western Mon- 
tana the call of the meadow lark as he sits on the top of a telephone pole or perches on a rock or fence is the first indication that warmer days are coming. The meadow lark is an interesting bird. It sings from the time it first comes in spring until it disappears in the fall. It has as many as eight different notes, and seems to take delight in alternating them while making its repertoire of music.

The meadow lark belongs to the oriole family. Its near relatives are the blackbirds and orioles. All of the family are ground feeders. They are provided with long and strong bills, fitted for digging in the ground, and for pulling worms out of the earth. The meadow lark nests on the ground, seeking some clump of bushes on the dry prairie, and there rears its young. It searches the vicinity for food for the infant larks. In meadows where the ground is under cultivation its habits are the same as in wild nature, save that it adapts itself to new conditions.

The meadow lark is one of the most useful of birds. From the fact that this is not generally appreciated it seems fitting that some little time be devoted to making a few statements in regard to its usefulness to man.

Practically nothing is to be said against the bird, and much in its favor. It is a great insect destroyer. Its choice food when it is to be had is the grasshopper. The bird is probably without a peer as an insect destroyer. It is a bird of good size, and hence requires a large amount of food, and is a diligent collector. An interesting article on the meadow lark by Prof. Beal is to be found in the Yearbook of the Department of Agriculture for 1895 . In this Prof. Beal gives the' following calculation in regard to its usefulness. "Remains of as many as 54 grasshoppers have been found in a single meadow lark's stomach but this is much above the average number usually eaten at one time. Such food, however, is digested rapidly, and it is safe to assume that at least 50 grasshoppers are eaten each day. If the number of birds breeding in one square mile of meadow land is estimated at five pairs, and the number of young that reach maturity at only two for each pair, or ro in all, there will be 20 birds on a square mile during the grasshopper season. On this basis, the birds would destroy 30,000 grasshoppers in one month. Assuming that each grasshopper, if let alone, would have lived thirty days, the thousand grasshoppers eaten by the larks each day represent a saving of 2.2 pounds of forage, 


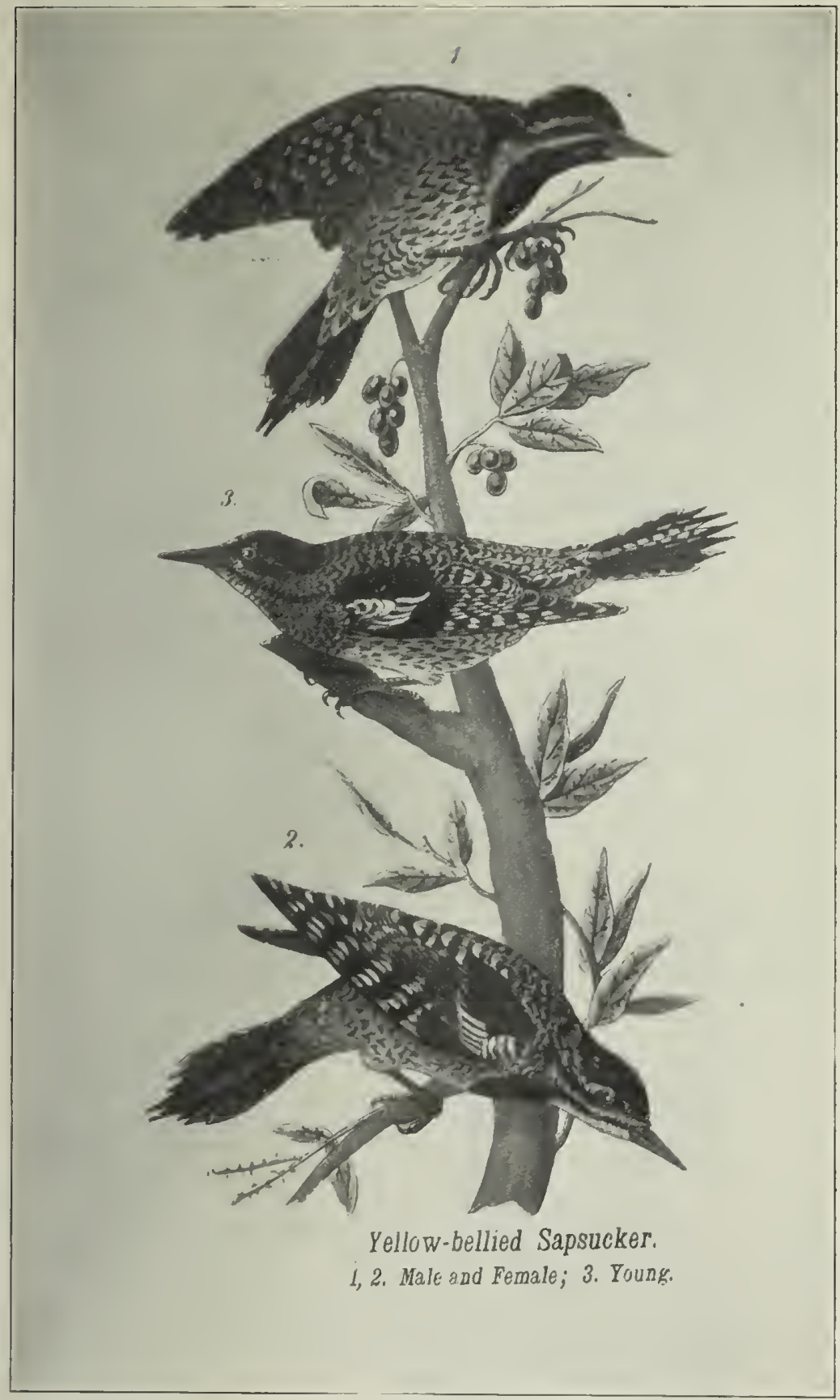

Yellow-bellied Sapsucker, Red-naped Sapsucker, Spyrapicus varius, From Birds of Pennsylvania. The western bird is var. nuchalis. 


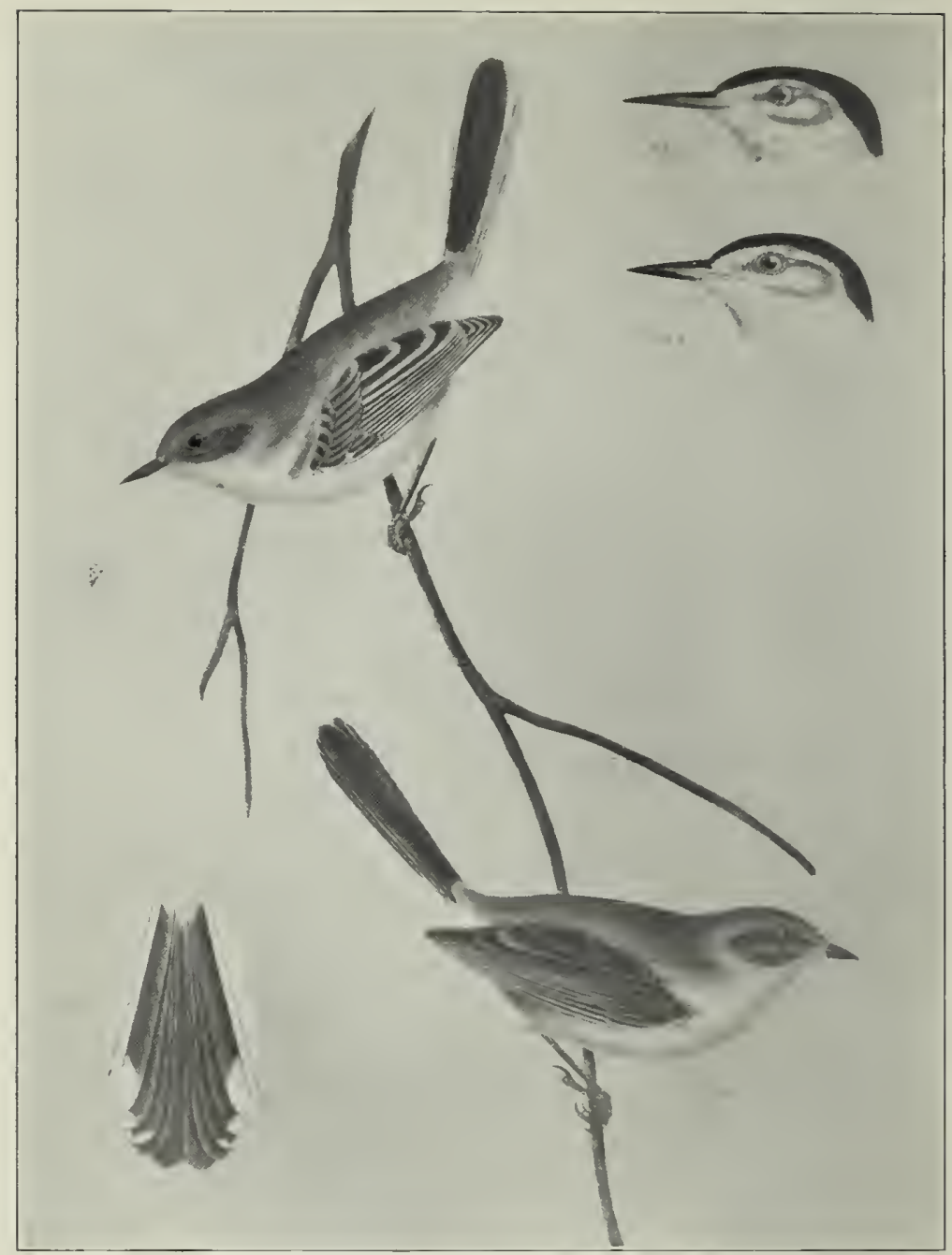

The lead-colored bush-tit, Psaltriparus plumbeus Baird, shown by the two birds and the figure of tail feathers. The upper heads are nuthatches. These are insect eating birds, as may be seen by the long sharp bills. From U. P. R. R. Survey. 
or 66 pounds in all for the month. If the value of this forage is estimated at $\$ 10.00$ per ton which is below the average price of hay in the eastern markets, the value of the crop saved by meadow larks on a township of 36 square miles each month during the grasshopper season would be about $\$ 24.00 . "$

More than half of the food of the meadow lark consists of harmful insects. Its vegetable food is composed of noxious weed seeds, waste grain, with some useful beetles, neutral insects and spiders. Although it is naturally an insect eater it can subsist on vegetable food if necessary, and as a consequence is not forced to migrate during cold weather any further than is necessary to secure food. In western Montana it not infrequently stays around barns during the winter, picking up refuse.

As stated before, the meadow lark is in some places considered a food bird. In Montana it is classed with the song birds, and permanently protected. It is entitled to all possible protection, and to slaughter it for game is a poor way to utilize so useful a bird.

It is impossible in the short space assigned to me to speak of many birds. There is one bird, however, that is harmful to the orchardist, which must not be overlooked. I refer to the rednaped sapsucker, Sphyrapicus varius nuchalis Baird. They do damage to trees by drilling holes in the bark of apple, thornapple and mountain ash trees, sometimes encircling the trees with these holes for a distance of two feet. They drink the sap of the apple tree, and in some cases kill the tree. Insects collect about the punctures of the tree thus made, and the bird later returns and makes a feast from the insects. The number of trees killed by this bird is not great, and large numbers of the insects which it destroys are harmful. It is therefore an open question as yet whether the bird should be killed for its attack on the trees or let live. The damage reported in the state is slight.

Lewis's woodpecker is the black bird, with a reddish breast and flight like a crow. It is a very abundant bird in the wooded portion of the western part of the state. It has been reported as doing damage to orchardists by pecking the apples while yet they hang to the tree, and thus making them unsalable. The amount of damage is not great, and it is rather surprising that this bird should take to eating fruit. As all the woodpeckers. 
are insect eaters orchardists should be very slow to kill the birds because of a little damage. The damage from a few insects is too well known to need argument. If it is a choice between two evils the lesser is likely to be chosen. The orchardist should examine the conditions carefully, and decide for himself. If the damage is great he should have the privilege of protecting his fruit. If it is small, he should be slow to kill.

Much damage is attributed to the hawks and owls, which are quite plentiful, especially in the wooded section. How much of the popular belief in hawk and owl mischief is true, and how much is false? The majority of the hawks and owls, as of other birds, are useful, and but a few are to be condemned. The popular belief that all hawks and owls should be shot on sight is not well founded. The damage done by hawks and owls is by carrying off poultry, small lambs and pigs. Some of them are very destructive to small birds which latter may be very useful. At least one species is hard on the grouse family, killing large numbers of game birds. Their benefit comes from their carnivorous habits. Instead of preying on poultry most of the species live on mice, gophers, ground squirrels, moles, and even insects. The little red hawk that is so abundant along the roads in the summer, hanging in mid air at times, again roosting on a post or rock, is a great enemy to the grasshopper, killing them by the thousands. So great is its capacity for the grasshopper that it goes by the name of grasshopper sparrow. Early in the spring and late in the fall it is severe on small birds, but its benefit far outweighs the destruction caused in killing birds.

Our largest bird is the great horned owl. This well known bird is fierce and untamable, and in strength and courage is inferior to none of our rapacious birds. The food is of great variety. It catches birds and mammals, fishes, crustaceans, and insects. Among birds it takes poultry, including half-grown turkeys, grouse, quail, doves, and wild ducks. Hawks, crows, and other fowls do not escape this rapacious bird, and large hawks are among those attacked and eaten. Dr. Fisher remarks of the species: "In studying this owl in relation to its food it will be perceived at a glance that a bird so powerful and voracious may at times be a source of great benefit, while at other times it may be the cause of great damage. Now, the serious inroads it makes on the tenants of the poultry yard, as 
well as the destruction of many game and song birds would seem to call for the total suppression of the species. Again, when engaged chiefly in the capture of injurious rodents, which threaten the very existence of the crops, it is the farmer's most valuable ally, and consequently should be most carefully protected." The rabbit stands at the head of the list of mammals most frequently eaten by this bird. It is said to be fond of spermophiles or ground-squirrels. It is reputed to be an expert rat catcher. It has been proven to eat mice and shrews, muskrats, woodchucks, and opossums. On one occasion a porcupine was attacked.

The bird inhabits wooded regions, where it finds both a home and an abundance of food. It is likely that in newly settled regions the bird may prove harmful, but as it disappears with the advance of agriculture its damage will not be for long.

Three birds may be mentioned which have brouglit the hawks and owls into disfavor. The sharp-shinned hawk, Accipiter velox, Cooper's hawk, Accipiter cooperi, and the goshawk, Accipiter atricapillus. The first two are much alike except in size. The illustrations accompanying will give a fair idea of the species, although it is to be regretted they are not in colors. Velox is an impudent and daring little bird from to to 14 inches in length, and little can be said in its favor. Its food is poultry and young birds, with occasional rodents. Cooperi is similar in appearance but larger, being from 14 to 20 inches long. It is much more to be dreaded than the preceding, as it is larger and stronger. Its food is about the same as that of velox, but it is a great enemy of the domestic pigeon, and will stay by a flock until it cleans them out or meets a tragic death. It is very fond of meadow larks, robins and flickers. One benefit derived from these two is that they have found the English sparrow a toothsome morsel, and easily obtainable, and have created great havoc among these birds in the eastern states. The goshawk is still larger than either of the two just mentioned, being $2 \mathrm{I}$ to 25 inches in length. It is bluish slate color above, top of head deep black, tail crossed by four dusky bands, white below, thickly barred with narrow zigzag lines of grey, feathers often streaked in the middle with dusky color. With us it is found usually only in the fall and winter, moving to the northern regions in the spring. It is especially bad on the grouse family, and is very destructive to poultry. It is the 
most daring of all birds, and many almost incredible stories are told relative to its boldness and daring. It will dart down at the feet of a farmer after a fowl, and even followed one into a house, where it was despatched with a stick.

The flight of the three species, as well as their general habits, may be readily studied by watching any one of them. They fly much alike, with great speed, and with accuracy. They are trim birds, with very sharp claws, and on account of their trim carriage, swift flight, boldness and daring, are easily recognized. They should be shot cn sight. But it is well to make no mistake in the decision, for the other birds except those mentioned are very useful.

The study of the birds will prove of both interest and profit to those who may be persuaded to find out more relative to our feathered friends. The literature suggested will be both interesting and profitable to the farmer and fruit-grower. At a comparatively small expense manuals may be secured which will enable the student to identify species. The subject is a big one, and full of interest and importance. It is but touched in this hasty sketch. Some of the literature suggested should be secured and read.

\section{Partial Bibliography.}

Preliminary report on the Food of Woodpeckers, by F. E. L. Beal. Bul. 7, Div. of Ornith. and Mam. U. S. Dept. of Agri. I895.

Some Common Birds in their Relation to Agriculture, by F. E. L. Beal. Farmers' Bulletin No. 54, U. S. Dept. of Agri. I897, $40 \mathrm{pp}$.

Birds as Weed Destroyers, by Sylvester D. Judd. Yearbook TT. S. Dept. of Agriculture, I898, pp. 219-232.

Four Conmon P.irds of the Farm and Garden, by Sylveste: D. J11!d. Yearbook of the U. S. Dept. of Agriculture for I895, p1). 4c:5-4I8.

The Meadow Lark and Baltimore Oriole, by F. E. L. Beal. Yearhocik, U. S. Dept. of Agriculture, pp. 419-430.

The Food of the Robin, by E. V. Wilcox. Ohio Experiment Station, Bul. 43, pp. II5-I32.

The Food of the Rotin, by S. A. Forbes. Bul. Ill. State Lab. of Nat. Hist., Vol. 1.; No. 3.

The Ornithological Balance-wheel, by S. A. Forbes. Trans. I11. State Hort. Soc. for I88I, printed Feb., I882, I2 pp. 


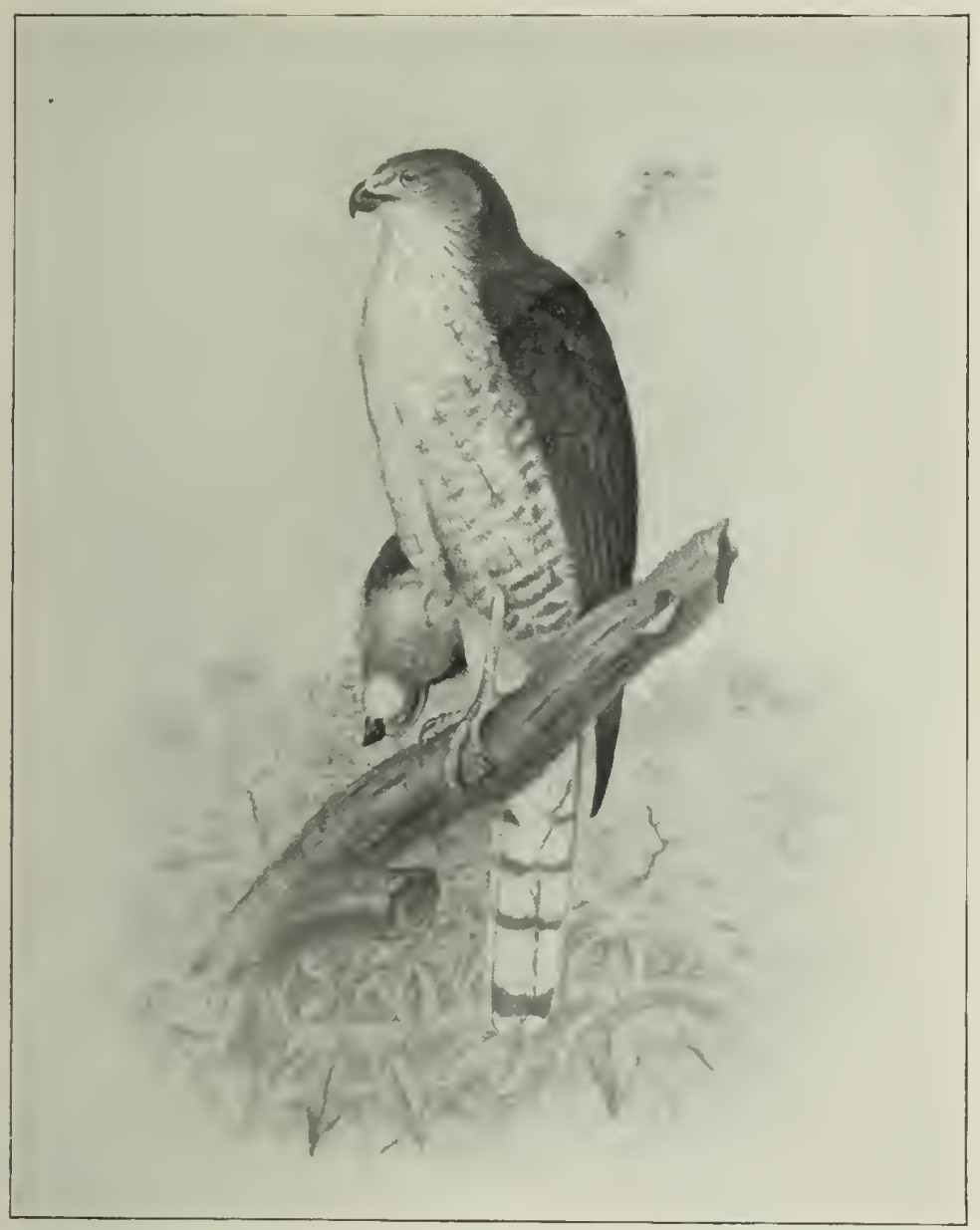

Sharp-shinned Hawik, Accipiter velox Wilson. From Biological Survey. 


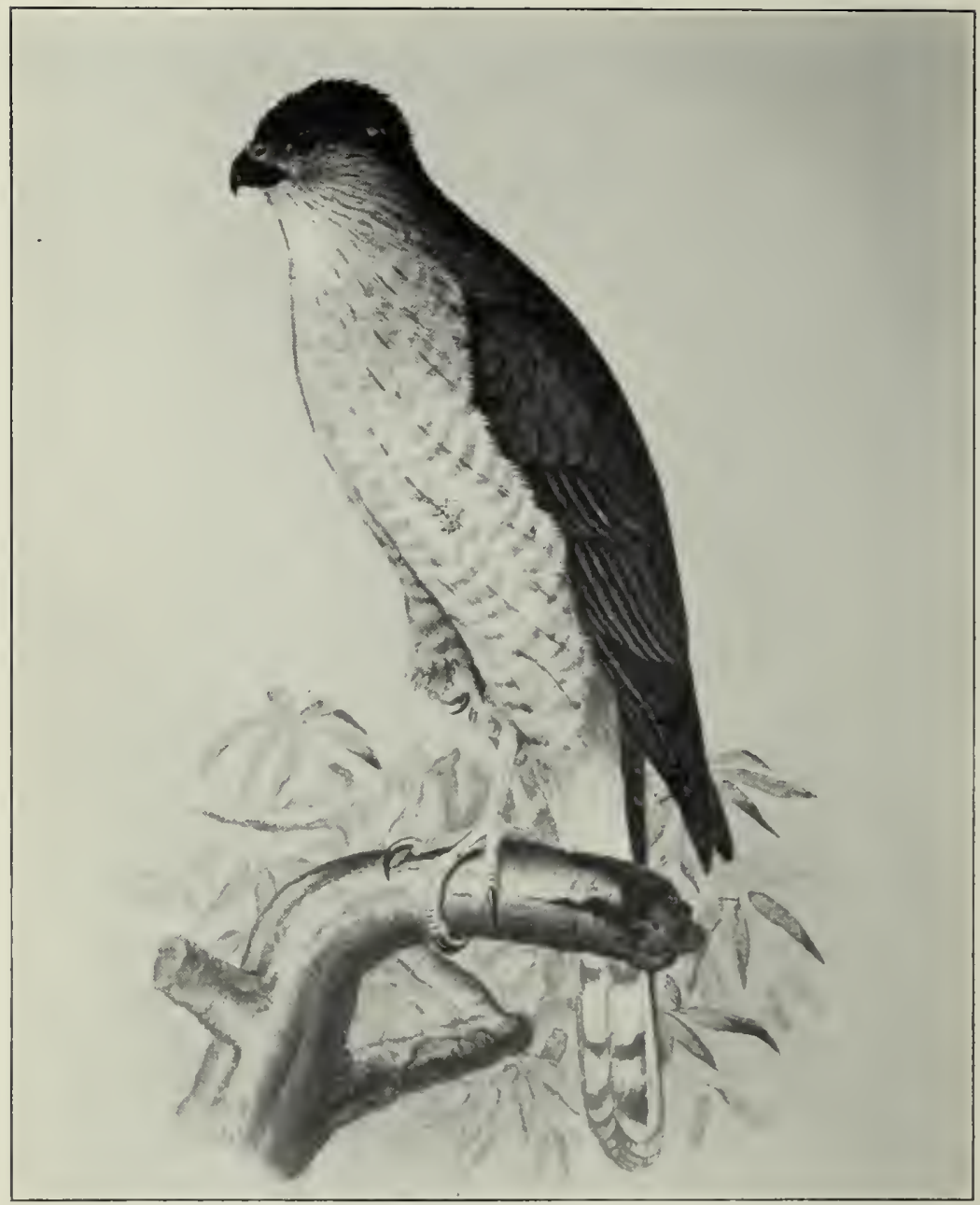

8

Cooper's Hawk, Accipiter, cooperi (Bonaparte). From Biological Survey. 
Birds in Horticulture, by Wm. E. Praeger. Trans. Ill. State Hort. Soc. New Ser., Vol. XXXIII, 9 pp.

The Hawks and Owls of the United States in their Relation to Agriculture, by Dr. A. K. Fisher. Bul. No., 3, Div. of Ornith. and Mam., U. S. Dept. of Agri. 2 Io pages, 25 colored plates. Out of print, but a very valuable work.

A Review of the Economic Ornithology of the United States, by T. S. Palmer. Yearbook of Department of Agriculture for I899, pp. 255-292, with several plates.

Legislation for the Protection of Birds other than Game Birds, by T. S. Palmer. Bul. No. I2, Revised edition, Division of Biological Survey, Washington. I44 pages, four maps, several illustrations.

Report of the Insect Food of the Crow, by E. A. Schwartz. Bul. No. 6, Div. of Ornith. and Mam., Washington, pp. 57-68.

Food of the Bobolinks, Blackbirds and Grackles, by F. E. L. Beal. Bul. No. I3, Division of Biological Survey, Washington, D. C. 78 pages and several illustrations.

The Relation of Sparrows to Agriculture, by Sylvester D. Judd. Bul. No. I5, Division of Biological Survey, Washington, D. C. 98 pages with several figures and plates.

Birds of a Maryland Farm, a Local Study of Economic Ornithology, by Sylvester D. Judd. Bul. No. I7, Division of Biological Survey. I I6 pages, I7 plates and many figures.

The Cowbirds, by Charles Bendire. From the Report of the United States National Museum for 1893, pages 587-624, with plates I-3.

The English Sparrow in North America, Especially in Its Relation to Agriculture, by Walter B. Barrows. Bulletin I, Division of Economic Ornithology and Mammalogy, U. S. Dept. of Agri., Washington. 406 pages.

Report on the Bird Migration in the Mississippi Valley, by W. IV. Cooke. Bul. No. 2, Div. of Economic Ornith., U. S. Dept. of Agri., Washington, D. C, 3 I4 pages

The Birds of Wyoming, by Wilbur C Knight. Bul. No.55, Wyoming Ex. Sta., Laramie, Wyo. $I_{74}$ pages, many plates.

A Partial Bibliography of the Economic Relations of North American Birds, by Clarence M. Weed. Tech. Bul. No. 5, New Hampshire, Col. Agri. Ex. Sta., Durham, N. H., pp. I37-I80.

Digest of Game Laws for Igor, by T. S. Palmer and H. W. 
Olds. Bul. No. I6, Div. of Biol. Sud., U. S. Dept. of Agri. I52 pages, plates and maps.

The Food of the Myrtle Warbler, by Clarence M. Weed and Ned Dearborn. Tec. Bul. No. 3, New Hampshire Agri. Ex. Sta., Durham, N. H., pp. II7-r28.

National Committee of Audubon Societies, 526 Manhattan Avenue, New York City Educational leaflets, each four pages, with half tone illustration.

No. I. The Nighthawk, Bull-Bat, Mosquito Hawk.

No. 2. The Mourning Dove.

No. 3. The Meadowlark.

No. 5. The Robin.

No. 5. The Flicker.

Birds in their Relation to Man, by Clarence M. Weed and Ned Dearborn. 380 pp., many plates and figures. J. B. Lippincott Co., Philadelphio.

Summer Birds of Flathead Lake, by Perley Milton Silloway. Bul. Univ, of Mont., Biol. Series No. I, 84 pp., plates IV-XVI. Univ. of Mont., Missoula.

Lectures Delivered at the University of Montana Biological Station at Flathead Lake in I902. Bul. Univ. of Mont., Biol. Series No. 5, pp. 19I-288, plates XLVII-LII, figs. 4-3I. Univ. of Mont., Missoula. (This has several helpful lectures on Birds.) Additional notes to Summer Birds of Flathead Lake, with special reference to Swan Lake, by Perley Milton Silloway. Bul. Univ, of Mont., Biol. Series No. 6, pp. 289-308, plates LIIILVII. Univ. of Mont., Missoula. 


\title{
THE WEALTH OF MONTANA AS SHOWN BY STATISTICS.
}

\author{
By. Morton J. Elrod, University of Montana.
}

Topography. The state has within its borders 9,49I,200 acres of land. Of this a monnt about $26,000,000$ acres are classed as mountain lands, $30,000,000$ as farming lands, and $38,000,000$ as grazing lands. This is approximately 40,000 square miles of mountains, 50,000 square miles of farming lands, and 56,000 square miles of grazing country. The mountain area of the state is about equal to the area of either Indiana, Kentucky, Virginia, Ohio, or Tennessee; its grazing land is more than the area of either Pennsylvania,Louisiana, Mississippi, or New York; its farming land is as much as the area of either Wisconsin, Iowa, Illinois or Michigan. The mountain area is largely in the western part. The main range of the Rocky mountains enters the state about a hundred miles east of the state line, and extends across the state from northwest to southeast, forming the boundary line between Montana and Idaho for several hundred milesfrom II4 meridian to the Yellowstone Park. The crest of the range is quite tortuous, and contains many peaks. West of the main range of the Rockies are several smaller ranges. The Bitter Root mountains form a large part of the boundary between Montana and Idaho, from 48 parallel to juncture with the main range of the Rockies. The northern portion of the state west of the main range includes the Kootenais, which extend northward into the British Possessions. Between the Kootenais and the Bitter Root range are the Cabinet mountains, extending approximately southeast and northwest, continuing westward into Idaho. They form the western boundary of the Flathead Indian reservation, the lower summits blending with the Mission range near Misoula. The mission range extends almost due north and south for about a hundred miles, the northern end beginning in the valley at the upper end of Flathead lake, 
rising higher and higher toward the south, culminating in McDonald Peak (9,800 ft.) Sinyaleamin Peak .9,500 ft.) and McLeod Peak $(9,000)$. East of the Mission range lies the Swan range, extending almost parallel with the former, and continuing some 30 or 40 miles farther north. Like the Mission mountains the Swan range is highest at the southern end, culminating in Swan Peak (I0,000). East of the main range are many smaller ranges, foothills leading from the Great Plains to the continental divide, with its high and snowy peaks. The Big Belt mountains form the boundary between Meagher county on the east side and Broadwater and Lewis and Clarke counties on the west. The range extends northwest and southeast for more than a hundred miles. In the southwest angle of the state, adjacent to the National Park, are many small ranges, including the Ruby mountains, the Tobacco-Root range, the Snow-Crest range, the Madison range, the South-Boulder range, the Gallatin range, Bridger mountains, and Snow mountains. Near the Wyoming line on the south is the small Bear-Tooth range, the Pryor mountains, the Rosebud range, with a high plateau in the southeast corner. The Little Belt mountains form a large portion of the boundary between Meagher county and Fergus and Cascade counties. Between this range and the Big Belts lie the small Dry Range and Elk mountains, while the Crazies are further to the southeast, and are the first high summits to greet the travlere on the Northern Pacific railroad as he speeds westward between Big Timber and Livingston.

Fergus county, in the central part of the state, is about as large as the state of Masachusetts. It contains the Big Snowy and Little Snowy ranges and the Moccasin mountains. North of the Missouri river the state is largely a great plain, broken by the Bear Paw range, culminating in Mt. Garfield (5,794 feet), and the Cherry-Patch hills at the northern boundary. The mountains contain many high peaks, the more lofty being in the Yellowstone Park region. Much of the mountainous region is yet unexplored save by the hardy trapper and prospector. The transcontinental railroads give the traveller a poor idea of the sublimity of the scenery which the many mountain ranges afford. Many of the snow clad peaks bear on their sides the remnants of glaciers, with miles of blue ice with huge crevasses, where the alpine climber may find untrodden and unnamed fields, where blue lakes reflect the azure depths of heaven, and where the bo- 
tanist, the zoologist, the geologist, as well as the artist, may find a virgin field. Many of the peaks, lakes, glaciers and creeks are unnamed. Some of the more important summits, other than thos mentioned, are the following. Mt. Powell, Deer Lodge County, I2,000; Chief Mountain, Io,000; Mt. LoLo, Bitter Root range, 9,500; St. Mary, Bitter Root range, 9,500; Electric Peak, near the Park, II,I55; G. N., I0,000; Sheep Mountain, I0,628; Ward, 10,267; Pentagon, 9,400.

The greater portion of the state lies east of the Rockies. Most of this section may be classed with the Great Plains region, traversed as it is by the mighty Missouri and its tributaries. Part of this Great Plains portion of the state is high and rolling, eminently adapted for grazing; but a large portion is adapted to farming, when irrigated, and will supply homes and farms for thousands of families in the years to come.

River Systems.-The waters from the mountains of Montana are carried by different river systems to the three oceans, the Arctic, the Pacific, and the Atlantic through the Gulf of Mexico. In the western part the Bitter Root river gathers the waters from the snow crests of the Bitter Root range.and from the spurs of the Rockies and unites with the Missoula near the city of Missoula. The Missoula river through its various tributaries gathers the water from a large portion of the western slope of the main range, including that which is used in the great smelters of Anaconda and which comes from the pumpings of the rich mines of Butte. Further north the North Fork, Middle Fork, and South Fork of Flathead River receive the drainage from the Mission and Swan Ranges, the west slope of the main range, and a part of the Kootenais. These unite to form the Flathead river, which first pours its waters into the greatest reservoir of the state, Flathead lake, and later joins the Missoula in the beautiful but narrow Paradise valley to form Clarke's Fork of the Columbia. The Kootenay river takes the drainage from the extreme northwestern corner, a part of the Columbia drainage system. The rivers on this western side are clear and swift, with rocky and picturesque canyons.

The Belly and St. Mary's rivers in the northern part of the main range carry the ice cold water from the glaciers of Chief mountain and the region adjacent on to the Arctic ocean. The sources of these two rivers are in the wildest and most picturesque portion of the state. If the plans of the National Gov- 
ernment are executed much of the water from the St. Mary's will be diverted to the Milk river and used in the vast system

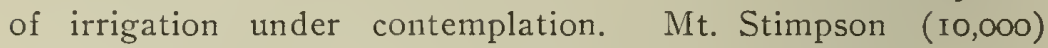
claims the proud distinction of sending its waters to three oceans.

By far the greater portion of the state is in the Missouri river drainage system. The Madison, Gallatin and Jefferson rivers gather the waters from the many small ranges adjacent to the Park and unite at Three Forks to form the Missouri. Near the city of Great Falls are the Falls of the Missouri, from which place the river is navigable to its juncture with the Mississippi. The Yellowstone river rises in Yellowstone lake in the Park, and after taking its two mighty leaps in the Park and flowing through its magnificent gorge it emerges as a restless river, continuing in swift descent until its waters merge with the muddy Missouri. The Yellowstone is the most rapid navigable stream in the world. From the north the Missouri receives the waters of the Marias, Teton, Sun and Milk rivers, all of which flow through valleys of great fertility. The scenery along the rivers is varied, and exhibits some striking antitheses. The valley of the Bitter Root is one of remarkable beauty. The river as it winds back and forth like a stream of silver, when viewed from Mt. Lo Lo, Ward's Peak, or St. Mary's in, the Bitter Root range is probably equalled in quiet and peaceful grandeur only by the Yellowstone as it flows through Hayden Valley in the Park. The three branches of the Flathead present to the few travelers along their courses many gorges and canyons. The South Fork in one place in the Lewis and Clarke Forest Reserve has cut its way through solid rock, making a canyon so narrow that pack horses may be and are forced to leap from brink to brink, while the river seethes and boils many feet below, its ominous roar announcing certain death if the leap is short. The Missouri has made the famous "Gateway of the Mountains," its splendor first told by Lewis and Clark, and later made famous by the brush of artists. At the City of Great Falls it hastens its speed before tumbling over the beautiful Black Eagle Falls, spanned by a bridge on the Great Northern railway, and does not diminish its speed until the bottom of the Great Falls is reached.

The valleys of these rivers and their smaller tributaries make rich farming soil, suitable for grain, vegetables and fruit. The Bitter Root valley in the west was settled first, and is a great 
farming and fruit raising region. The country adjacent to Flathead lake is thickly settled, and produces abundant harvest without irrigation. The Gallatin valley has become famous for its bountiful harvests, and the Yellowstone is being largely used for agriculture and fruit. The northern tributaries of the Missouri, while watering very fertile valleys, are in a thinly settled region.

Climate and Rainfall.-The climate of the state is exceedingly varied, and is much more salubrious than is generally supposed. West of the range the winters are mild, the summers and falls delightful. The rainfall at Misoula and Kalispell averages about 16 inches, while at Culbertson and Glendive in the eastern end of the rainfall is about $\mathrm{I} 3$ inches. Rain or snow prevails during the spring until early July. July, August and September are largely without rain, although in many places there is no need of irrigation. Owing to the different altitudes snow may fall later in the spring at some places than at others. An area of 30,700 square miles is below 3,000 feet elevation above the sea; this is equivalent to a state the size of Georgia. About I0,200 square miles exceed 8,000 feet altitude. The climate on the Pacific slope is milder and less changeable than that of the Atlantic side. The majority of the areas of high barometer, an ${ }^{3}$ accompanying cold, originate in the Arctic regions, and are deflected southward or eastward by the Rocky mountains. While eastern Montana and the Dakotas may be in the throes of a blizzard, the western end may be enjoying balmy weather. The coldest record at Missoula for $2 \mathrm{I}$ years is -22 degrees $F$, while in some winters the thermometer does not go below the zero point. The mean temperature at Missoula is 44 degrees $F$. At Helena, altitude 4,500, the mean temperature is $34 \mathrm{I}$. Chinook winds may occur over the entire state, melting large quantities of snow in a short period of time. Owing to the usual absence of a high percentage of humicity the cold weather is not extremely disagreeable, nor the warm days smotheringly oppressive. The hot days may blister the the skin, while the nights following will be cold enough to require blankets. Rarely does one sleep without considerable covering, and some people wear the same clothing summer and winter, donning extra coats or wraps in winter. This may be given as the general summary: the springs are rainy; the summers are clear and dry; the autumns are delightful; the winters are 
clear and bracing. Owing to the absence of high humidity the climate is very beneficial to health, as statistics will show. It is especially beneficial to those affected with pulmonary diseases.

Agriculture and Husbandry.-In the early days of Montana's history it was not thought possible to grow crops in the state to much extent. Nearly everything was shipped in from the outside. As the mines developed the demand for food became so great as to stimulate agriculture. Fruit raising was also attempted. Marked success attended the efforts, and larger acreage of grain and orchards was put out annually, until agriculture and husbandry have developed into important economical features in the state's progres, and bid fair to rank close to the mineral wealth in the near future. In 1902 nearly a quarter of a million fruit trees were set out; the number was almost dnubled the succeeding year. At the close of the year 1903, nearly one and a half million fruit trees had been set out in various parts of the state. The harvest in that year was a quinter of a million bushels of apples. The trees in the orchards include apples, cherries, plums, apricots, and peaches. Small fruit, such as gooseberries, strawberries, blackberries, curan: $\varsigma$, and the like, produce enormous crops from small acreage, while to describe the size and weight of the fruit is almost bey. nnd belief. Apples are shipped to the eastern states and even to England. As they are remarkably free from insect pests, owing to stringent legislation and watchful care in orchard inspection, home grown apples are constantly in demand, the demand being.far in excess of the supply. As a small part of the total number of trees bears fruit at the beginning of 1904, the insufficient supply is accounted for, but the crop of the orchards will increase in amount very rapidly. The Bitter Root valley, in the western part of the state on the Pacific slope, is the oldest orchard section, and is fast becoming famous as a fruit growing valley. But the orchards are not confined to this beautiful and fertile valley. The valley to the north of Flathead lake is filled with orchards already breaking beneath their loads of fruit. The Yellowstone valley is developing rapidly as a fruit growing region, even growing grapes. The most recent observations show that fruit trees may be grown and that apples will mature in every portion of the state, and apples are now grown in every county in the state with but a few exceptions. Horticulturists insist that fruit trees may be grown in every county in the state. 
Since the portion of the state east of the Rocky mountains is much greater than that on the west the fruit growing possibilities of the state may be readily understood when it is known that the great majority of the fruit trees of the state are on the Pacific side.

The total value of farm property in I 900 was $\$$ II $7,859,823.00$, an increase of I43.I per cent in ten years; that of farms, including farm improvements, and buildings, $\$ 36,513,750.00$, an increase of I 43.I per cent in ten years; that of implements and machinery, $\$ 2,315,890.00$, or I 70.8 per cent; and that of live stock, $\$ 30,541$,I46.00, or I4I.3 per cent increase. The value of farm products for I 889 exceeds that reported for 1899 by $\$ 22,343,542.00$, or 356.2 per cent increase. Of the total, land area of the state II,844,454 acres, or 12.7 , per cent, were included in farms in 1900 . The average size of the farms was 885.9 acres, of which 14.7 per cent was improved land. The total number of farms was I 3,370 , an increase of nearly 250 per cent in the decade. The total acreage in farms in 1900 was almost 85 times that repurted in 1870. Eastern Montana contains more than three-fifths of the total area of the state. In the extreme eastern part lies the "Bad Lands," a continuation of the "Bad Lands" of the Dakotas, Wyoming and Nebraska, parctically non-irrigable because of its uneven surface. The Yellowstone valley has become famous for its growth of alfalfa, where two or three cuttings, a total of 4 to 6 tons per acre, are had. The Gallatin, Madison and Jefferson valleys in the southeast produce rich harvests of cereals, never failing through irrigation. In the west the Bitter Root, Missoula and Flathead valleys, while less extensive, produce as abundant harvests, often without irrigation. The lands are of three general classes - the bottom lands, near the streams, with rich, black, alluvial soil; the bench lands, whose soil is a sandy loam, capable of wide range of cultivation; and the high bluffs, suitable largely for grazing. Experiments in "dry land farming," farming on the uplands without irrigation, in I9O3 indicate that good crops may be grown in this way, and the method is encouraged by the Experiment Station. 90.8 per cent of the farms are operated by the owners thereof. The entire Crow Indian reservation is included in the statistics as one farm, thus making the average size quite large. Nearly three hundred farms were operated by the Indians, twentysix by Chinese and twenty-one by negroes. This was about 0.4 per cen of the total 
farm acreage. The government plans for irrigation will reclaim large tracts of land and put it under cultivation. The crops raised are corn ( 75,838 bushels); wheat ( $1,899,638$ bushels); oats (4,746,23 I bushels); barley ( 844, I 40 bushels); rye (32,120 bushels); hay and forage (1,059,361 tons); dry peas ( 32,265 bushels); potatoes ( $1,332,062$ bushels in 1899$)$; other crops in small quantity, making a total valuation of $\$ 1,692,515$. During the past few years, many small fruit and truck farms have been started, promising greater returns per acre and greater variety of farm products, as ready market awaits all kinds of farm produce.

Montana leads the Union in the number of sheep, there being more than five million in IgO2. The sheep industry has proven profitable in the eastern portion where there is much open range. Few herds are to be found west of the range. The fleeces weighed thirty-five and a half million pounds, valued at over six million dollars. In 1902 there were three-quarters of a million of cattle and one-fifth of a million of horses, the assessed valuation of the former being $\$ 3,121,000.00$, and of the latter $\$ 3,900,000.00$.

Timber and Lumber. -29 per cent of the total area of the state is covered with timber, which is 8 per cent less than for the average of the entire United States. The timber growth is largely of coniferous trees, yellow pine, tamarack, and Douglas spruce comprising the most of the commercial products. Along the streams occur forests of cottonwood. In the drier portions of the state stunted red cedars often grow along the smaller water courses, of great value to settlers, as they supply posts and wood. Forests of white cedar, or arbor-vitae, white pine and Engelmann's spruce occur in the western part. On the higher slopes and summits the alpine species thrive; but as they are limbed to the base of the tree and inaccessible they are not of value commercially. They are useful in preventing the rapid melting of snow in the spring, holding it until later in the season when it is needed in irrigation. A considerable portion of the state's timbered area is included in government forest reserves. On the west the Bitter Root reserve includes a portion of the Bitter Root range within the state, and since the higher summits are not in the water shed of the range, but far to the east of it, the reserve includes territory from which comes the water to irrigate the fertile Ritter Root valley. In the north is 
the Lewis and Clarke reserve, formed by the union of the original Lewis and Clarke reserve, the Flathead reserve, and a narrow strip along the Great Northern Railway which was originally not included in either. In the southeastern part is the Gallatin reserve. In 1902, the same year in which the proclamation was made for the Gallatin reserve, proclamations were issued setting aside the Little Belt Mountain reserve, the Madison and the Absaroka reserves. The area embraced in each is as follows:

I. Lewis and Clarke, 6,732 square miles, or 4,308,480 acres, not including the narrow strip along the Great Northern ra11way. 2. The Bitter Root, 6,480 square miles, 450,000 acres of which are in Montana, the remainder in Idaho. 3. The Gallatin, 63 square miles, or 40,320 acres. 4. The Little Beit, 503,040 acres, including the town of Neihart and the Yogo sapphire mine. 5. The Madison, 800,000 acres. 6. The Absaroka, $1,385,000$ acres. The total of all land in government forest reserves in the state in 1902 was $7,487,400$ acres, nearly II,700 square miles, or about one-thirteenth of the total land area of the state.

The total output of the lumber mills in 1902 was $210,047,000$ feet of rough lumber, 5,500,000 shingles, and 17,000,000 lath. The United States Geological Survey in 1902 estimated all of the merchantable timber on all of the reserves in the state at 14,$974,800,000$ feet. On state land there was estimated to be 912,ooo,000 feet, making the total estimate of merchantable timber on state or government land I $5,886,800,000$ feet. This estimate does not include timber in the Northern Pacific land grant, nor on the land belonging to private owners and milling companies, At the present rate of consumption the timber on state and government land would satisfy the mills as running in 1902 for about 70 years.

Mines and Mining.-Montana has been known principally on acount of her mines, and leads in the production of copper and in the output of sapphires. The early history of the states is the search for gold, and many of her towns and cities are built in suiches where placer gold was mined. Virginia City and Helena are illustrations, the former being the oldest mining camp in the state. Although Butte is the greatest mining camp in the state, and, indeed, the greatest in the world, it is by no means the only place where mining is carried on. In 1900 mining for gold and silver was carried on in the following counties: Beaver- 
head, Broadwater, Cascade, Chouteau, Custer, Deer Lodge, Fe1 gus, Flathead, Granite, Jefferson, Lewis and Clarke, Madiso1 Meagher, Missoula, Park, Ravalli and Silver Bow. Lewis an Clarke was the greatest producer, with 70,000 fine ounces of gol and I72,53 I fine ounces of silver. The total product of gold an silver in the state in I 900 was 229, II 4 ounces of the former an $\mathbf{I} 4,294,835$ of the latter. In I90I, there were 232,33 I ounces $C$ gold and I4,I80,545 ounces of silver. During the forty year following the discovery of gold in the state over one billion do lars in value of gold, silver, copper and lead have been taken fror the streams and mountains of the state. While Butte is th mining camp for copper, it is also mined in the counties of Bea erhead, Granite, Jefferson, Lewis and Clarke, Madison an Meagher. Butte, in Silver Bow County, produced 227,742,26 pounds of the total of $228,03 \mathrm{I}, 503$ pounds from the state in I 901 Lead was produced in all the counties mentioned except Madi son, and in addition also in Broadwaater, Cascade and Flatheac The total lead output in that year was more than eleven and half million pounds, and in 1902 it was nearly sixteen million.

Montana is one ot the richest coal states in the west, althoug much of it is undeveloped. Two million tons were mined it I902, and new mines are being opened annually. The Creta ceous bituminous and semi-bituminous coal areas in the stat cover about I3,000 square miles, and the lignite area about 25 , ooo. Not all of this territory contains coal, of course, but th deposits are found quite abundantly throughout the territory The tests show the bituminous coal to be but little inferior t Pennsylvania bituminous coals. Bituminous coal or lignite ha been found in every county of the state except Jefferson. Th undeveloped coal industry will without doubt be a prominen factor in the future expansion of other industries of the state In addition to its coal the state has extensive beds of clay; th brick and clay product in 1902 amounted to a half million dollars The output of building stone was about the same.

Montana leads the Union in the production of sapphires, th actual mining of which began in I89I. Four mining regirn may be mentioned: A belt I2 miles northeast of Helena on th Misouri river; the Rock creek region 30 miles west of Anaconda the Cottonwood creek field Io miles east of Deer Lodge, and the Fogo mines in Fergus county, I3 miles west of Utica. The an nual output of sapphires in the state in 1902 was between 450,00 
and 500,000 karats, including those suitable for cutting and those used for mechanical purposes. A lapidary at Helena employed I 5 men, and it is asserted that finer work is done there than on stones sent to London.

Manufactures.-The predominating industry is the smelting of ores. The largest smelter in the world, the Washoe, is located at Anaconda. For the treatment of ores waten is brought from a lake some $\mathrm{r}_{5}$ miles away in the mountains. The smelters of Butte have long been known. At Helena a large smelter is in operation, and another at Great Falls, where water power from the Missouri river is used. Many flouring mills have been established, utilizing almost the entire crop of wheat in the state, and consuming large quantities from the Dakotas. The large lumber mills at Bonner, Hamilton, Somers, and other places have extensive factories in connection with the saw mills. They manufacture doors, sash, blinds and other finishing stuffs. They also make large quantities of furniture from native lumber. A woolen mill, in operation in Big Timber, established in rgor, consumes a considerable amount of the wool product. Although Montana leads all other states in the number of sheep, the loss from the two items of freight eastward, and the difference in the value of the wool in the grease and the scoured product, will annihilate the value of all the flocks on the range of the state in 10 years, 7 months and 9 days, if the wool is all shipped to the east. To treat it in the state' will save $\$ 1,000,000$ annually to the state. Nearly every large town has a factory for malt liquors. Creameries and butter factories are springing up. The transcontinental railways have several repair shops and round houses in the state. A biscuit and cracker factory is located' at Helena and does a large business. In I900 $\mathrm{I}, 000$ establisments, representing a capital of $\$ 40,945,846$, were operating in manufactures and mechanical industries. The value of the product, $\$ 57,075,824$, involved an outlay of $\$ 837,97 \mathrm{I}$ for salaries of officials, clerks, etc., $\$ 7,969,886$ for wages, $\$ 1,668$,487 for miscellaneous expense, and $\$ 31,702,650$ for materials, ight and fuel. The value of manufactured products in ten years from 1890 to 1900 increased ten fold, or more than $I, 000$ per cent and more than thirty times the value in 1870 .

Railroads.-The total mileage of railroads in 1902 was 3,I3I.87 miles, with 572.14 miles of side track. During that year and the year preceding 199.5 miles of road were constructed, not 
including large expenditures for betterment of track on existing road. Two transcontinental lines cross the state. In the north is the Great Northern, with its many branch lines. Toward the southern part is the Northern Pacific, also with numerous short branch lines as feeders. The Burlington connects with the latter at Billings, running through trains over the N. P. tracks to the coast. The N. P. operates three daily passenger trains each way over most of the state-as far east as Billings, where one takes the Burlington route for Denver, Omaha and St. Louis. The Great Northern operates two daily passenger trains each way over its road. The Oregon Short Line connects at Butte, making a gateway to Salt Lake and the south, east and west. From one end of the state to the other on the Northern Pacific requires about 24 hours of travel, following for considerable distances the Missoula, Missouri, Gallatin and Yellowstone rivers, with their varied scenery. The Great Northern skirts the banks of the Kootenay, the Flathead, the Milk, and the Missouri rivers, and gives a view of the great unoccupied field along the two latter.

Finances.-The total assessed valuation of all property in the state in I902 was $\$ 183,395,690$. The constitution of the state prohibits an indebtedness exceeding $\$ 100,000$. The tax rate was less than $\$ 2.50$ per $\$ 1,000$. 